\title{
PERNIKAHAN BEDA AGAMA PERSPEKTIF HUKUM ISLAM DAN HUKUM POSITIF DI INDONESIA
}

\author{
Ahmad Fuadi \& Devi Anggreni Sy \\ Dosen Fakultas Hukum Universitas Bina Insan \\ e-mail : ahmadfuadi@univbinainsan.ac.id dan devi_anggreni@univbinainsan.ac.id
}

\begin{abstract}
Abstrak
Dalam Islam Perkawinan beda agama dilarang oleh kebanyakan ulama. Hal ini merujuk pada al-Qur'an surat al-Baqarah ayat 221 dan Qur'an surat al-Mumtahanah ayat 10, Namun akibat adanya pandangan yang berbeda tentang hukum perkawinan beda agama, hal ini berdasarkan Alquran surat al-Ma"idah ayat 5. Disamping itu juga terdapat kontradiktif tentang aturan pernikahan beda agama antara Pasal 56 Undang-Undang No. I Tahun 1974 Tentang Perkwainan yang membuka peluang untuk dilakukannya pernikhan beda agama dengan Kompilasi Hukum Islam Pasal 44 Kompilasi Hukum yang menutup sama sekalai pernikahan beda agama. Oleh sebab itu banyak terjadi perkawinan beda agama di kalangan umat Islam, dan menimbulkan masalah yaitu bagaimana kawin beda agama ini dipandang baik menurut hukum Islam, dan hukum positip Indonesia. Penelitian ini bersifat diskriptik analitik dengan menggunakan pendekatan yuridis normatif. Data yang sudah terkumpul dianalisa secara kualitatif dengan metode berfikir deduktif dan induktif. Pada akhirnya nanti dapat disimpulkan bahwa hakikat pernikahan adalah sebuah kontrak sosial, sehingga segala hal mengenai pernikahan sudah seyogyanya dikembalikan pada nilai-nilai subyektifitas yang akan melaksanakannya, sekalipun terdapat pelarangan seharusnya lebih bersifat sosiologis, bukan teologis dan realisasinyapun harus melalui fakta yang empirik bukan hanya prasangka-prasangka yang mengakibatkan sentimen kolektif terhadap komunitas lain.
\end{abstract}

Kata Kunci : Pernikahan Beda Agama, Hukum Islam, Hukum Positif

\begin{abstract}
In Islam Marriage of different religions is forbidden by most scholars. This refers to the Qur'an surah al-Baqarah 22I and Qur'an surah al-Mumtahanah 10, But due to the different views on the law of marriage of different religions, this is based on the Qur'an surah al-Ma"idah 5. In addition, there are also contradictions about the rules of marriage of different religions between Article 56 of Law No. I of 1974 on Marriage that opens the opportunity for marriage of different religions with the Compilation of Islamic Law Article 44 Compilation of Laws that closes the same time as marriages of different religions. Therefore, there are many different religious marriages among Muslims, and cause problems, namely how to marry different religions is considered good according to Islamic law, and Indonesian positip law. This research is analytically described using normative juridical approaches. The collected data is analyzed qualitatively with deductive and inductive thinking methods. In the end it can be concluded that the nature of marriage is a social contract, so that everything about marriage should be returned to the values of subjectivity that will carry it out, although there is a prohibition should be more sociological, not theological and the realization must be through empirical facts not just prejudices that result in collective sentiment towards other communities.
\end{abstract}

Keywords: Marriage Of Different Religions, Islamic Law, Positive Law

Pendahuluan

Sudah menjadi sunnatullah bahwa makhluk hidup di dunia ini diciptakan oleh Allah Swt berpasang-pasangan. Hidup berjodoh-jodohan adalah naluri segala makhluk hidup untuk melestarikan keturunan. (Djaman, 1993, hal. 5) Secara naluriah, seorang pria membutuhkan wanita, dan begitu juga sebaliknya, meskipun demikian, agar perasaan saling membutuhkan ini tidak berubah menjadi bumerang, maka Islam telah mengatur tata cara melakukannya.

Islam memandang bahwa perkawinan merupakan suatu hubungan yang ideal yang tidak hanya mempersatukan antara laki-laki dan perempuan, akan tetapi perkawinan merupakan suatu kontrak sosial dengan seluruh aneka ragam tugas dan tanggung jawab sehingga memunculkan hak dan kewajiban antara keduanya.

Perkawinan merupakan salah satu bagian terpenting dalam kehidupan berkeluarga dan bermasyarakat, sebab itu itu dalam memilih suami atau istri Islam sangat menganjurkan agar segala sesuatunya didasarkan atas norma agama, sehingga pendamping hidup nantinya mempunyai akhlak yang terpuji, tidak ada suatu ketimpangan terhadap suatu keyakinan. Hal ini dilakukan agar keluarga tersebut 
dapat hidup secara damai, tentram, sejahtera, kekal, bahu membahu dan saling tolong menolong sehingga terciptalah kehidupan keluarga yang harmonis sesuai dengan asas pekawinan yakni selamanya (tidak temporal). (Junaedi, 2000, hal. 46) Tujuan mulia ini dapat dilaksanakan melalui jalan perkawinan yang sah menurut agama, diakui oleh undang-undang dan diterima sebagai bagian dari budaya masyarakat. (Rofiq, 1997, hal. 220)

Permasalahan kawin beda agama adalah permasalahan yang krusial, tepatnya pada tahun delapan puluhan dipandang sebagai sesuatu yang sangat merisaukan ummat Islam. (Karsayuda, 2006, hal. 3-4) Di kutip dari jurnal Sanawiah Indonesia merupakan salah satu negara multikultural terbesar di dunia. Hal ini dapat dilihat dari kondisi sosiokultural, agama maupun geografis yang begitu beragam dan luas. Sekarang ini, jumlah pulau yang ada di wilayah Negara Kesatuan Republik Indonesia (NKRI) sekitar 13.000 pulau besar dan kecil. Populasi penduduknya berjumlah lebih dari 200 juta jiwa, terdiri dari 300 suku yang menggunakan hampir 200 bahasa yang berbeda. Selain itu mereka juga menganut agama dan kepercayaan yang beragam seperti Islam, Katolik, Kristen Protestan, Hindu, Budha, Konghucu serta berbagai macam aliran kepercayaan. (Sanawiah, 2017)

Seorang muslim yang hidup di negara yang majemuk seperti ini hampir dipastikan sulit untuk menghindari dari pergaulan dengan orang yang berbeda agama. Pada posisi seperti ini ketertarikan pria atau wanita muslim dengan orang yang berbeda agama dengannya atau sebaliknya, yang berujung pada pernikahan hampir pasti tidak terelakkan. Dengan kata lain, persoalan pernikahan antar agama hampir pasti terjadi pada setiap masyarakat yang majemuk. Masyarakat yang berbeda agama bisa menjalin suatu ikatan yang mengarah kepada suatu perkawinan beda agama yang pada akhirnya hal tersebut akan memunculkan suatu permasalahan yang kemudian berakibat pada munculnya banyak pendapat mengenai sah atau tidaknya perkawina ini, baik sah menurut agama ataupun negara. Fenomena perkawinan beda agama bagi sebagian umat Islam di Indonesia merupakan sebuah fenomena ganjil, keganjilan ini muncul dari pemahaman masarakat tentang Islam itu sendiri yang memiliki kerancuan dan cenderung negatif.

Kalau dilihat dari prespektif hak asasi manusia jelas membentuk keluarga melalui perkawinan itu merupakan hak preogratif pasangan calon suami dan istri yang sudah dewasa dan mampu untuk menikah. Kewajiban negara adalah melindungi, mencatatkannya dan menerbitkan akte perkawinan, realita semacam ini tidak cukup disadari oleh negara.

Dalam memahami perkawinan beda agama menurut undang-undang perkawinan di indonesia setidaknya ada tiga penafsiran yang berbeda. Pertama, bahwa perkawinan beda agama adalah merupakan pelanggaran terhadap UU No. I//974 Pasal 2 ayat I jo Pasal $8 \mathrm{f}$. Pendapat kedua, bahwa perkawinan beda agama adalah sah dan dapat dilangsungkan, karena telah tercakup dalam perkawinan campuran, dengan argumentasi pada pasal 57 tentang perkawinan campuran yang menitik beratkan pada dua orang yang di Indonesia tunduk pada hukum yang berlainan, yang berarti pasal ini mengatur perkawinan antara dua orang yang berbeda kewarganegaraan juga tentunya mengatur dua orang yang berbeda agama. Pendapat ketiga bahwa perkawinan beda agama sama sekali tidak diatur dalam UU No. I/1974, oleh karena itu berdasarkan Pasal 66 UU No. I//974 maka persoalan perkawinan beda agama dapat dikembalikan kepada peraturan perkawinan campuran, karena belum diatur dalam undangundang perkawinan. (Barkatullah, 2006, hal. I47148) 
Akibat dari pemahaman yang berbeda tersebut diatas muncul berbagai anggapan bahwa pengaturan dan penataan aturan tentang perkawinan beda agama tidak mengarah kepada kesamaan dan keseragaman. Perbedaan ini itu tidak hanya pada agama yang satu dengan yang lainnya, bahkan satu adat masyarakat dengan adat yang lain pun juga berbeda, (Aibak, 2006, hal. 39) begitu juga dalam satu agama, ketidak samaan juga muncul dalam memahami hukum tentang pernikahan beda agama, hal ini karena adanya pemahaman dan cara berfikir yang berbeda, perbedaan cara pandang tersebut dilatar belakangi oleh kultur sosial yang melingkupinya. Dan kemudian cara pendang yang berbeda ini mengkristal menjadi berbagai mazhab atau aliran.

Dalam Islam interpretasi pernikahan beda agama, juga terpola menjadi tiga macam, Pertama, melarang secara mutlak. sebagian ulama melarang secara mutlak pernikahan antara muslim dan nonmuslim, baik yang dikategorikan musrik maupun ahli kitab dan larangan itu berlaku, baik bagi perempuan muslim maupun laki-laki muslim. Pandangan seperti ini sebagaimna yang difatwakan oleh MUI (Majelis Ulama Indonesia). Kedua, membolehkan secara bersyarat, sebagian ulama membolehkan pernikahan laki-laki muslim dengan perempuan non muslim dengan syarat perempuan non muslim itu dari kelompok ahlul kitab. Ketiga, membolehkan pernikahan antara orang muslim dan non muslim, dan kebolehan itu berlaku untuk lakilaki dan perempuan, larangan pernikahan lintas agama sudah tidak lerevan lagi, didalam Alquran sendiri tidak pernah secara tegas melarang hal itu, karena Alquran menganut pandangan universal tentang martabat manusia yang sederajat, tanpa melihat perbedaan agama. Segala produk hukum Islam klasik yang membedakan kedudukan orang Islam dan non Islam harus diamandemen berdasarkan prinsip kesederajatan universal dalam tatanan kemanusiaan. (Abdalla, 2002)

Bertitik tolak dari realitas yang ada ini penulis merasa terpanggil untuk membahas lebih mendalam tentang polemik perdebatan seputar pernikahan beda agama, salah satu yang masih diperdebatkan adalah dasar hukum untuk menyatakan keabsahan dan ketidak absahan pernikahan tersebut. Oleh karena itu menjadi menarik, persoalan nikah antar pemeluk agama ini untuk dibahas.

\section{Pembahasan}

Salah satu kebijakan negara Indonesia dalam persoalan klasik yang masih menjadi isu aktual dalam wacana hukum Islam adalah wacana perkawinan beda agama, Undang-undang Nomor I Tahun 1974 tentang Perkawinan, telah memberikan ketentuan yang bersifat nasional, dalam kaitannya untuk menyaring berbagai persepsi yang selama ini berkembang dalam pengertian perkawinan yang timbul akibat pluralisme hukum dalam masyarakat Indonesia yang berkaitan dengan masalah hukum keluarga.

Walaupun aturan tentang perkawinan ini telah ada dalam Undang-undang Nomor I Tahun 1974, tidak berarti bahwa Undang-undang ini telah mengatur semua aspek yang berkaitan dengan perkawinan. Contoh persoalan yang belum diatur oleh Undang-undang Perkawinan adalah perkawinan beda agama.

Perkawinan beda agama terjadi apabila seorang yang berbeda keyakinan dalam beragama melakukan pernikahan dengan tetap mempertahankan agamanya masing-masing, bila pernikahan ini terjadi, pertanyaan yang mendasar adalah bagaimanakah hukum pernikahan tersebut? "pertanyaan ini tidak akan dijumpai jawabannya dalam Undang-undang No I Tahun 1974,” karena Undang- undang ini mengembalikan suatu keabsahan perkawinan kepada agamanya masing- 
masing, hal ini termaktub dalam pasal 2 ayat I berbunyi "Perkawinan adalah sah, apabila dilakukan menurut hukum masing- masing agamanya. Sedangkan di dalam agama itu sendiri terdapat penafsiran yang berbeda-beda terkait masalah hukum pernikahan beda agama, disamping itu dalam Undang-undang No I Tahun 1974 juga terdapat pasal yang membuka peluang untuk dilakukannya pernikhan beda agama yaitu Pasal 56 tentang pernikahan yang dilakukan di luar negeri. Pengalaman beberapa orang menunjukkan bahwa pernikahan beda agama dapat dilakukan dengan cara menikah di luar negeri, yang di negara tersebut dilegalkan pernikahan semacam ini seperti Australia, Singapura, Amerika Serikat, Hong Kong dan Inggris. Perkawinan artis Yuni Shara misalnya sebagai seorang muslimah menikah dengan Henry Siahaan yang beragama Kristen Protestan secara dibawah tangan, kemudian disahkan di Perth, Australia pada tanggal 7 Agustus 2002, contoh lain perkawinan artis Christian Sugiono yang beragama Kristen dengan artis Titi Kamal yang beragama Islam, mereka menikah pada tanggal 6 Februari 2006 di Australia. Kenapa mereka melakukan pernikahan di luar negeri karena di Indonesia tidak ada aturan yang mengatur tentang pernikahan beda agama tersebut. (Halim, 2016, hal. 69) Kontroversi mengenai sah atau tidaknya perkawinan beda agama yang dilakukan di luar negeri dilihat dari sudut pandang perundang-undangan di Indonesia. (Aibak, 2006, hal. 40-4I) Telah minimbulkan suatu tanda tanya besar, apakah disini terjadi kekosongan hukum atau terjadi sebuah penyelundupan hukum.

Sebenarnya sebelum diundangkannya Undang-undang Perkawinan Nomor I Tahun 1974, di Indonesia sudah pernah berlaku peraturan hukum antar golongan tentang pernikahan campuran, yaitu Regeling op de Gemengde Huwelijken (GHR) atau peraturan tentang perkawinan campuran sebagaimana dimuat dalam yang

Staatblad 1898 Nomor I58. (Himpunan Peraturan Perundang-Undangan Republik Indonesia, 1989)

Beberapa pasal di atas secara tegas mengatur tentang perkawinan beda agama bahkan disebutkan bahwa perbedaan agama tidak dapat dijadikan alasan untuk mencegah terjadinya perkawinan. Kemudian dengan berlakunya Undangundang Perkawinan Nomor I Tahun 1974, seperti disebut dalam pasal 66, maka semua ketentuanketentuan perkawinan terdahulu sepanjang telah diatur dam Undang-undang teersebut dinyatakan tidak berlaku. (R. Tama, 1984, hal. 148)

Dalam Kompilasi Hukum Islam pasal 40 huruf c dan pasal 44 secara eksplisit mengatur tentang larangan perkawinan antara laki-laki muslim dengan wanita non-muslim dan wanita muslim dengan laki-laki non-muslim. Pasal 40 huruf c Kompilasi Hukum Islam menyatakan sebagai berikut

Dilarang melangsungkan perkawinan antara seorang pria dengan seorang wanita karena keadaan tertentu;

a. Karena wanita yang bersangkutan masih terikat satu perkawinan dengan pria lain;

b. Seorang wanita yang masih berada dalam masa iddah dengan pria lain;

c. Seorang wanita yang tidak beragama Islam.

Pasal 40 huruf c diatas secara eksplisit melarang terjadinya perkawinan antara laki-laki (muslim) dengan wanita non-muslim. Jadi pasal ini memberikan penjelasan bahwa wanita non muslim apapun agama yang dianutnya tidak boleh dinikahi oleh laki-laki yang beragama Islam.

Pengesahan Kompilasi Hukum Islam dengan menggunakan Instruksi Presiden No. I Tahun 199I dan tidak menggunakan undang-undang memunculkan permasalahan mengenai kekuatan hukum Kompilasi Hukum Islam, di kalangan Ahli Hukum ada yang mengatakan bahwa Kompilasi 
Hukum Islam tidak mengikat (fakultatif). Hal ini Presiden No.I Tahun 1991 dinyatakan sebagai berikut:

a) Bahwa Alim Ulama Indonesia dalam lokakarya yang diadakan di Jakarta pada tanggal 2 sampai dengan 5 Februari 1988 telah menerima baik tiga rancangan buku Kompilasi Hukum Islam, yaitu Buku I tentang Hukum Perkawinan, Buku II tentang Hukum Kewarisan, dan Buku III tentang Hukum Perwakafan.

b) Bahwa Kompilasi Hukum Islam tersebut dalam huruf a oleh Instansi Pemerintah dan oleh masyarakat yang memerlukannya dapat dipergunakan sebagai pedoman dalam menyelesaikan masalah-masalah dibidang tersebut.

c) Bahwa oleh karena itu Kompilasi Hukum Islam tersebut dalam huruf aperlu disebar luaskan.

Argumen lain yang diajukan adalah bahwa dalam konsideran point b Instruksi Presiden No. I

Tahun 199I dinyatakan; Bahwa Kompilasi Hukum Islam tersebut dalam huruf a oleh instansi pemerintah dan oleh masyarakat yang memerlukanya dapat dipergunakan sebagai pedoman dalam menyelesaikan masalah-masalah dibidang tersebut. Ungkapan dapat dipergunakan sebagai pedoman menunjukan bahwa Kompilasi Hukum Islam tersebut tidak mengikat secara imperatif. Oleh karena itu para pihak dapat menjalankannya dan dapat pula untuk meninggalkannya, sesuai dengan kebutuhan dan keperluannya. dengan demikian maka pedoman disini memiliki pengertian bersifat fakultatif. Oleh karenanya dalam praktek orang yang mengenyampingkan Kompilasi Hukum Islam tidak dapat dipersalahkan telah melanggar hukum.

Kendatipun sudah sangat jelas dalam Kompilasi Hukum Islam terkait maslah hukum pernikhan beda agama, tidak memberikan ruang atau menutup sama sekali keabsahannya, penulis berasumsi bahwa larangan tersebut tentu saja perlu dikritisi lebih lanjut karena beberapa hal yaitu, Pertama sebagai satu negara yang sudah memiliki instrumen hukum berupa Undang-Undang No. 39 dapat dibuktikan dalam konsideran Instruksi Tahun 1999 tentang HAM, idealnya negara menjamin kebebasan warganya untuk memilih pasangannya dalam membentuk sebuah keluarga. Hak untuk memilih pasangan hidup merupakan kebebasan yang harus diakui keberadaannya oleh negara. Berdasarkan pasal 10 ayat (I) dalam undang-undang tersebut, dinyatakan bahwa setiap orang berhak untuk membentuk suatu keluarga dan melanjutkan keturunan melalui perkawinan yang sah dan atas kehendak yang bebas. Kenyataannya, negara justru membatasi perkawinan tersebut. Kedua, Indonesia bukan negara teokrasi dan bukan pula negara sekuler sehingga di dalam pembentukan hukum nasional, pemerintah harus bisa menjamin kepastian hukum kepada seluruh lapisan masyarakat tanpa melihat agama dan kepercayaan yang dianut, termasuk dalam persoalan perkawinan beda agama. Ketiga, perkawinan antar agama secara objektif sosiologis adalah wajar karena penduduk Indonesia memeluk bermacam-macam agama dan UUD 1945 menjamin kemerdekaan beragama bagi setiap penduduknya sehingga tentu saja terbuka kemungkinan terjadinya dua orang berbeda agama saling jatuh cinta dan pada akhirnya membentuk sebuah keluarga. Keempat, akibat tidak diaturnya ketentuan mengenai perkawinan beda agama dalam UndangUndang No I Tahun 1974, maka hal tersebut membuka ruang terjadinya penyeludupan hukum. Untuk memenuhi persyaratan formal secara perdata, suami-istri berbeda agama "rela" melangsungkan pernikahan di luar negeri tanpa memperhatikan hukum agama, atau malah yang lebih parah salah satu pihak melakukan pura-pura dengan berpindah agama (konversi agama).

Jika dianalisa secara kritis, tampak bahwa persoalan hak asasi manusia muncul dalam kasus perkawinan beda agama berkaitan dengan pasal 2 ayat (I) UU No. I tahun 1974 dan pasal 2 ayat (2) 
Peraturan Pemerintah No. 9 Tahun 1975 tentang Pencatatan Perkawinan sebagai peraturan Pertama, soal sahnya perkawinan. Dalam pasal 2 ayat (I) diatas terlihat bahwa sahnya perkawinan tergantung apabila dilakukan menurut hukum masing-masing agamanya dan kepercayaannya. Ketentuan ini hanya dapat dilaksanakan manakala kedua mempelai memiliki agama yang sama. Kalau keduanya memiliki agama yang berbeda, maka boleh jadi, ada empat cara yang lazim ditempuh pasangan beda agama yang akan menikah yakni, pertama, meminta penetapan pengadilan terlebih dahulu. Atas dasar penetapan itulah pasangan melangsungkan pernikahan di Kantor Catatan Sipil. Tetapi cara ini tak bisa lagi dilaksanakan sejak terbitnya Keppres No. 12 Tahun 1983. Kedua, perkawinan dilangsungkan menurut hukum masing-masing agama. Perkawinan terlebih dahulu dilaksanakan menurut hukum agama seorang mempelai (biasanya suami), baru disusul pernikahan menurut hukum agama mempelai berikutnya. Permasalahannya perkawinan mana yang dianggap sah? Apakah perkawinan menurut hukum yang kedua (terakhir)? Jika ya, apakah perkawinan pertama dianggap tidak sah? Ketiga, kedua pasangan menentukan pilihan hukum. Salah satu pandangan menyatakan tunduk pada hukum pasangannya. Dengan cara ini, salah seorang pasangan „berpindah agama" sebagai bentuk penundukan hukum. Di sini terlihat adanya penyelundupan hukum dimana salah satu pihak secara pura-pura beralih agama kemudian setelah pernikahan di anggap sah menurut negera salah satu dari mereka kembali kapada agama yg sebelumnya hal ini lumrah terjadi pada masyarakat. Keempat, yang sering dipakai belakangan, adalah melangsungkan perkawinan di luar negeri. Beberapa artis tercatat memilih cara ini sebagai upaya menyiasati susahnya kawin beda agama di Indonesia. Masalahnya, apakah kawin beda agama di pelaksana UU Perkawinan. Problem HAM yang muncul adalah luar negeri sah menurut hukum Indonesia? Jika ingin dipertajam lagi, mengapa warga negara Indonesia tidak mendapatkan perlindungan hukum di dalam negerinya sendiri, tetapi justru ingin mendapatkan perlindungan hukum dari negara lain? Bukankah hal tersebut sungguh ironis?

Masalah-masalah di atas tentu tidak harus terjadi jika saja pemerintah lebih memahami bahwa hak asasi manusia adalah hak yang dimiliki oleh setiap manusia yang hidup yang bukan merupakan pemberian siapapun juga termasuk negara, sedangkan hak sipil adalah hak warga negara yang menimbulkan kewajiban bagi negara untuk melindungi, mengakui dan memproteksinya.

Hal ini penting untuk diperhatikan karena persoalan perkawinan beda agama dalam konteks Negara Indonesia adalah persoalan hukum, sementara tafsiran agama-agama tentang pernikahan beda agama adalah persoalan teologis dan tafsir-tafsir keagamaan. Oleh karena Indonesia bukan negara agama, maka yang menjadi acuan adalah hukum nasional. Meskipun hukum nasional, seperti Undang-Undang Perkawinan No. I Tahun 1974 mendasarkan diri pada apa yang dikatakan dengan hukum agama, namun cendrung lebih terikat pada dasar filosofi bangsa yang Bhineka Tunggal Ika. Artinya, prinsip mengakui keragaman bangsa dan kemajemukan masyarakat haruslah menjadi dasar dari pembentukan dan pembuatan suatu hukum maupun undang-undang yang bersifat nasional.

Pembahasan mengenai pernikahan beda agama, khususnya mengenai pernikahan seorang yang muslim dengan orang yang non muslim dalam perspektiif Hukum Islam, tentunya berangkat dari penelusuran terhadap sumber pokok ajaran Islam yaitu Alquran dan hadis. Terkait masalah pernikahan beda agama ini terdapat penjelasan di 
dalam Alquran surat al-Mumtahanah ayat 10 dan alBaqarah ayat 221:

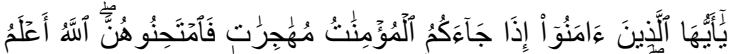

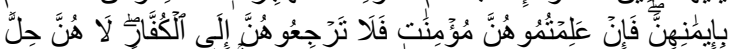

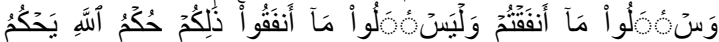

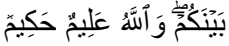

Hai orang-orang yang beriman, apabila datang berhijrah kepadamu perempuan-perempuan yang beriman, maka hendaklah kamu uji (keimanan) mereka. Allah lebih mengetahui tentang keimanan mereka; maka jika kamu telah mengetahui bahwa mereka (benar-benar) beriman maka janganlah kamu kembalikan mereka kepada (suami-suami mereka) orang-orang kafir. Mereka tiada halal bagi orang-orang kafir itu dan orang-orang kafir itu tiada halal pula bagi mereka. Dan berikanlah kepada (suami suami) mereka, mahar yang telah mereka bayar. Dan tiada dosa atasmu mengawini mereka apabila kamu bayar kepada mereka maharnya. Dan janganlah kamu tetap berpegang pada tali (perkawinan) dengan perempuanperempuan kafir; dan hendaklah kamu minta mahar yang telah kamu bayar; dan hendaklah mereka meminta mahar yang telah mereka bayar. Demikianlah hukum Allah yang ditetapkan-Nya di antara kamu. Dan Allah Maha Mengetahui lagi Maha Bijaksana.

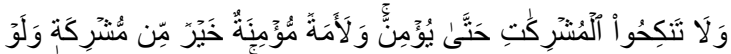

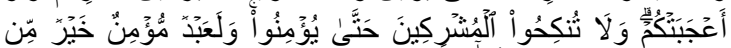

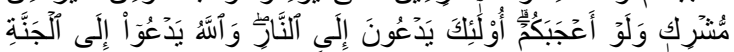

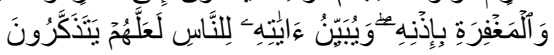

Dan janganlah kamu menikahi wanita-wanita musyrik, sebelum mereka beriman. Sesungguhnya wanita budak yang mukmin lebih baik dari wanita musyrik, walaupun dia menarik hatimu. Dan janganlah kamu menikahkan orang-orang musyrik (dengan wanita-wanita mukmin) sebelum mereka beriman. Sesungguhnya budak yang mukmin lebih baik dari orang musyrik, walaupun dia menarik hatimu. Mereka mengajak ke neraka, sedang Allah mengajak ke surga dan ampunan dengan izin-Nya. Dan Allah

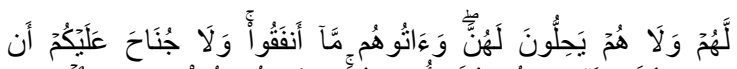

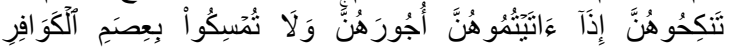

menerangkan ayat-ayat-Nya (perintah-perintah-Nya) kepada manusia supaya mereka mengambil pelajaran.

Ayat ini mencoba menjelaskan bahwasanya merupakan larangan yang besar bagi seorang yang beragama Islam menikahi wanita-wanita musyrik, bahkan ditegaskan bahwa seorang budak jauh lebih baik dari wanita-wanita musyrik, hal ini juga berlaku sebaliknya, bagi seorang muslimah juga diharamkan menikahi laki-laki musyrik, karena di dalam ayat ini baik laki- laki ataupun wanita musyrik hanya akan mengajak ke jalan menuju neraka.

Disamping terdapat ayat yang menjelaskan tentang larangan menikahi wanita dan laki-laki musyrik, dalam Alquran juga terdapat penjelasan yang memperbolehkan laki-laki muslim menikahi wanita-wanita dari golongan ahl al-Kitab, kebolehan ini termaktub dalam Alquran surat al-Ma'idah ayat 5:

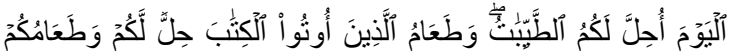

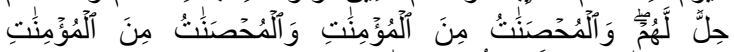

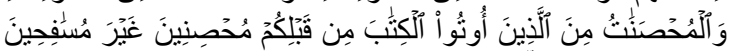

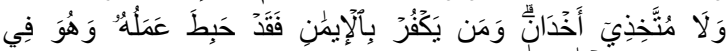



Pada hari ini dihalalkan bagimu yang baik-baik. Makanan (sembelihan) orang-orang yang diberi Al Kitab itu halal bagimu, dan makanan kamu halal (pula) bagi mereka. (Dan dihalalkan mangawini) wanita yang menjaga kehormatan diantara wanitawanita yang beriman dan wanita-wanita yang menjaga kehormatan di antara orang-orang yang diberi Al Kitab sebelum kamu, bila kamu telah membayar mas kawin mereka dengan maksud menikahinya, tidak dengan maksud berzina dan tidak (pula) menjadikannya gundik-gundik. Barangsiapa yang kafir sesudah beriman (tidak menerima hukum-hukum Islam) maka hapuslah amalannya dan ia di hari kiamat termasuk orang-orang merugi. 
Pada ayat ini diterangkan tentang kehalalan bagi umat islam akan segala hal yang bernilai baik yang diberikan dari ahl al-Kitab, dan halal juga baginya (umat Islam) melakukan sebaliknya (segala hal yang bernilai baik) kepada ahl al-Kitab,

Berangkat dari ayat-ayat ini akhirnya para ulama ataupun seorang ataupun segolongan orang yang mengerti tentang studi ke Islaman baik klasik maupun kontemporer mencoba menginterprestasi apa yang dimaksud oleh ayat-ayat Alqur"an ini sehingga melahirkan penafsiran yang berbeda.

Untuk menjawab pertanyaan ini penulis berangkat dari persoalan apakah pernikahan itu tergolong ke dalam bentuk ibadah atau muamalah, pertanyaan berikut jelas merupakan hal yang sangat penting sebagai bekal untuk menjawab persoalan keabsahan hukum pernikhan beda agama. Pasalnya, sering kali banyak orang yang mencampur-adukkan antara nilai-nilai ubudiah yang terdapat dalam pernikahan (munakhat) di satu sisi, dan perbuatan muamalah di sisi yang lain. Faktor semacam inilah yang kerap merancukan perbedaan dan perdebatan pendapat di semua kalangan untuk "menghukumi” pernikahan beda agama.

Az-zawaj (pernikahan), paling sedikit menurut kalangan syafiiah, itu merupakan bagian integral dari perbuatan duniawi (al"amal alduniyawiyah) tepatnya urusan muamalah sebagaimana perbuatan jual beli/ bisnis (al-bay"), sewa menyewa (al-ijarah), gadai (ar-rahn), dan lainlain. Pendeknya pernikhan itu tidak termasuk kedalam perbuatan ibadah murni (ibadah mahdah), meskipun didalamnya mengandung nilai-nilai ibadah. Intinya sebuah pernikahan itu bukan merupakan ibadah dalam arti ibadah murni. (al-Zuhaili, 20II, hal. 35) Diantara alasanya sebagaimana pernah diuraikan dibab sebelumnya adalah mengingat pernikahan yang dilakukan orang-orang (pasangan) kafir dan kafirah itu hukumnya tetap sah. Kalau pernikhan itu dikategorikan kedalam perbuatan termasuk kehalalan didalamnya untuk menikahinya, bahwa dengan penegasan menikahi ahl al-Kitab untuk menjaga kehormatannya dan bukan untuk berzina ataupun hal-hal lainnya yang tidak dibenarkan oleh agama ibadah, maka seharusnya akad nikah yang dilangsungkan oleh pasngan kafir kafirah (non muslim) itu hukumnya tidak sah, ayah dan ibunda rasulullah saw (Abdullah dan Aminah) sendiri melakukan akad nikah dengan adat istiadat yang berlaku di zamanya, namun nabi Muhammad saw sendiri menyatakan keabsahan pernikhan ayah ibunya ketika beliau menyatakan bahwa dirinya dilahirkan sebagai anak yang sah, bukan lahir dari hasil perzinahan (walidtu min nikahin, wala min sifahin). (Suma, 20I5, hal. 92)

Ini menunjukan pengakuan sah semua pernikahan yang dilakukan semua pasangan non muslim. Lagi pula, tujuan utama dari sebuah pernikahan pada dasarnya dan pada umumnya adalah untuk memenuhi kebutuhan (kepuasan) syahwat pribadi (syahwat an-nafs), sedangkan tujuan dari amal ibadah adalah demi amal itu sendiri kepada Allah Swt semata-mata, dan amal yang semata-mata karna Allah, tentu akan lebih tinggi kedudukannya maupun nilainya dibandingkan dengan amal yang dilakukannya semata-mata untuk kepentingan diri sendiri (motif pribadi). Hal yang akan penulis garis bawahi dalam bagian ini adalah pendapat ulama yang menyatakan bahwa pernikahan tidak tergolong dalam perbuatan ibadah murni, akan tetapi lebih tepat tergolong ke dalam perbuatan hukum muamalah meskipun tetap berdimensikan ibadah. Poin ini bagaimanaupun menjadi penting untuk disertakan dalam melakukan pembahasan "pernikahan beda agama”.

Penetapan akad pernikahan ke dalam bentuk hukum muamalah, selain dapat dipahami dari defenisi akad nikah itu sendiri yang mencerminkan keberadaan kedua pihak dalam hal ini suami istri, 
juga terutama harus dilakukan dengan melalui ijab kabul yang menjadi rukun esensial sebuah pernikahan, dan diperkuat dengan keharusan adanya para saksi nikah, di samping harus ada wali nikah bagi perempuan minimal menurut sebagian ulama, fakta lainnya adalah kenyataan penempatan bahkan tidak ada yang mencantumkannya didalam bagian kitab/bab "al-ibadat", hal ini merupakan argumentasi lain untuk menetapkan urusan nikah masuk dalam wilayah muamalah, hal ini dapat diperhatikan dari buku-buku Hadis dan Fiqh, antara lain: Sayyid Imam Muhammad bin Ismail al-Kahlani al-San"ani, Subul as-Salam, yang menempatkan pembahasan kitab nikah sesudah kitab bisnis, alImam Taqy ad-Din Abi Bakr bin Muhammad alhusaini al-Syafi"i, Kifayah al-Akhyar fi Halli Ghayah alIkhtishar, yang juga mencantumkan kitab nikah sesudah pembahasan muamalah.

Permasalahan yang mendasar tentang terjadinya perbedaan terkait hukum pernikhan beda agama, selain pernikahan masuk dalam kategori ibadah atau muamalah adalah masalah interprestasi yang beragam terhadap dasar hukum pernikahan beda agama, kebanyakan para ulama figh mendasarkan hukum pernikahan beda agama kepada ayat yang sama yaitu Alquran surat alBaqarah ayat 22I, Qs. al-Mumtahanah ayat I0, dan Qs. al-Ma"idah ayat 5. Mencermati ketiga ayat tersebut, ada beberapa poin penting yang tepat dan releven untuk diangkat dalam pembahasan kali ini.

Pertama, secara tekstual maupun kontekstual, surat al-Baqarah ayat 221 dengan tegas melarang orang tua/wali yang beragama Islam untuk menikahkan laki-laki musyrik dengan wanitawanita muslimah, atas alasan apapun dan dengan motivasi apapun juga, demikian menurut sebagian dan bahkan merupakan ijmak ulama. Dalam istilah Wahbah al-Zuhayli, keharaman laki-laki muslim menikahi wanita kafirah/musyrikah, meliputi wanita-wanita yang tidak beragama dengan agama kajian atau tepatnya pembahasan pernikahan dalam hampir semua literatur tafsir, hadis dan terutama kitab-kitab fikih, dimana meletakan pernikahan (annikah / al-tazwij) dalam kelompok kitab/bab "almuamalat",

samawi, yaitu wanita yang menyembah selain Allah, semisal menyembah berhala, api, binatang, dan lain semisalnya. Yusuf Qardhawi dalam hal ini juga mengharamkan perkawinan antara laki-laki muslim dengan wanita musyrikah. Namun terdapat perberdaan pendapat di antara para ulama yakni tentang siapa musyrikah yang haram dinikahi sebagaimana maksud ayat di atas. Menurut Ibnu Jarir al-Thabari, bahwa musyrikah yang dilarang dinikahi adalah musyrikah dari bangsa Arab saja, karena bangsa Arab pada waktu turunnya.

Alquran memang tidak mengenal kitab suci dan mereka menyembah berhala. Menurut Yusuf Qardhawi, konteks ayat 22I surat al-Baqarah di atas, secara keseluruhan beserta asbabun nuzulnya menunjukkan bahwa yang dimaksud dengan alkawafir (perempuan-perempuan kafir), yakni alwatsaniyat (perempuan-perempuan penyembah berhala). (Qardhawi, 1996, hal. 580) Hal yang sama juga di utarakan dalam tafsir lbnu Katsir, dijelaskan, melalui ayat ini Allah mengharamkan atas orangorang mukmin menikahi wanita-wanita yang musyrik dari kalangan penyembah berhala. Maka menurut pendapat ini, seorang laki-laki muslim boleh menikah dengan wanita musyrikah dari nonArab, seperti wanita Cina, India, Jepang, dan Indonesia yang diduga mempunyai kitab suci atau serupa kitab suci. Muhammad Abduh juga sependapat dengan hal ini. (Rasyid Ridha, hal. 187190) Tetapi mayoritas ulama berpendapat bahwa semua musyrikah baik dari bangsa Arab maupun non-Arab selain ahli kitab tidak boleh dinikahi. Menurut pendapat ini, siapapun yang bukan muslim 
atau ahli kitab (beragama Kristen atau Yahudi) haram dinikahi. (Zuhdi, I99I, hal. 5)

Terkait masalah term musyrik yang haram dinikahi penulis lebih cenderung kepada musyrik ahl Makah, karna melihat hukum dari pengaharaman pernikahan beda agama ini yang terdapat dalam surat al-Baqarah tidak bisa dilepaskan dari konteks

Wacana larangan pernikahan beda agama tersebut terjadi pada masa awal hijrahnya nabi Muhammad, sebagaimana asbab an-nuzul ayat tersebut terkait kasus Abu Martsad dan kekasihnya Inaq adalah lingkungan sempit pewahyuan, adapun situasi wacananya, menurut penulis, lebih mengacu kepada perjumpaan Muhammad dengan komunitas musyrik di Makkah yang bertahun-tahun menganiayanya sehingga memaksanya mengungsi ke Madinah. Inaq sebagai sosok musyrik Makkah sehingga dalam membaca surat al-Baqarah 221 dan al-Mumtahanah ayat 10, kita harus memproyeksikan benturan-benturan nabi Muhammad dengan orang-orang musyrik Makkah sebagai unsur yang ikut memberi kontribusi dalam pembentukan teks al-Baqarah ayat 221 dan alMumtahanah ayat 10.

Benturan benturan yang dilancarkan oleh kaum musyrik Quraisy sangat gencar, hal ini bisa kita lihat dalam sejarah-sejarah pendakwahan nabi Muhammad di Makkah, pihak Quraisy juga melakukan teror fisik kepada pengikut-pengikut Muhammad, tidak jarang kaum muslimin disiksa dan dipaksa melepaskan agamanya, kekerasan seorang tuan kepada budaknya yang muslim juga sering terjadi. Seperti kasus Bilal pengikut setia Muhammad, suatu kali pernah dicampakkan di atas pasir di tengah terik matahari dan dadanya ditindih dengan batu sampai-sampai ia mau meninggal, ada pula seorang perempuan yang disiksa sampai meninggal karena ia tetap teguh dalam agamanya. (Haikal, 2003, hal. 127) Demikianlah dari hari ke hari kekerasan kepada minoritas muslim terus turunya ayat, apa yang akan penulis coba tekankan disini adalah memperlihatkan suatu wacana yang mengondisikan pelepasan dan penangkapan suatu pesan, karna bagaimanapun juga dalam situasi wacana terdapat kekayaan segala hal yang ikut membangun konstruksi wacana yang dihasilkan.

dilancarkan, kondisi semacam ini menyadarkan nabi betapa kota Makkah dengan penduduk Quraisynya adalah tantangan yang terlalu besar bagi dirinya, Inilah faktor yang menyebabkan nabi Muhammad dan kaum muslimin hijrah ke Madinah.

Pada situasi wacana seperti inilah ayat Alquran surat al-Baqarah ayat 221 dan alMumtahanah ayat 10 yang kemudian diklaim sebagai ayat yang melarang pernikahan beda agama, ketika nabi Muhammad sudah tiba ditempat yang baru, yaitu Madinah, sebagian muslim masih terpenjara di Makkah, karenanya nabi Muhammad kemudian mendelegasikan Abu Martsad untuk membantu evakuasi kaum muslim yang masih tinggal di Makkah. Setelah melanjutkan tugasnya, Abu Martsad kembali ke Madinah dengan membawa persoalan tentang keinginan kekasihnya Inaq yang berstatus kafir ingin mengajaknya menikah, oleh sebab itu sangat wajar apabila muncul ketetapan larangan tersebut. Jadi bisa dikatakan Qs. al-Baqarah ayat 221 ini memiliki dimensi politik yang sangat kuat, karena dari hal tersebut tergambar dengan jelas adanya pertimbangan politik yang bagi kehidupan awal Muhammad di Madinah masih traumatik dengan benturan kekerasan dari kalangan kafir Quraisy Makkah, selain itu juga pada waktu itu secara nomerik (jumlah) umat Islam sangat sedikit dibandingkan orang musyrik.

Kedua secara tekstual, surat al-Ma'idah ayat 5 dengan tegas menghalalkan laki-laki muslim menikahi wanita kitabiyah yang muhsanat (memelihara kesucian dirinya) namun tidak 
sebaliknya yaitu laki-laki ahlulkitab menikahi wanitawanita muslimah, dalam ayat ini yang dimkasud ahlulkitab adalah kelompok atau komunitas pemeluk agama yang memiliki kitab suci yang diwahyukan oleh Allah kepada nabi dan rasulnya. (Ghalib, 1998, hal. 20)

Yahudi dan Nasrani adalah dua kelompok agama yang diakui mempunyai kitab suci, karena kepada keduanya diturunkan kitab suci, yakni dan kebatilan. sedangkan pujian Alquran yang diberikan kepada ahl al-kitab adalah karena ada diantara mereka yang membaca ayat-ayat Allah, mengikuti ajaran nabi, dan juga dapat dipercaya. Alquran dan nabi Muhammad saw., menamakan orang-orang Yahudi dan Nasrani sebagai ahl alkitab untuk membedakan mereka dengan para penyembah berhala, yakni orang-orang musyrik. Walaupun kitab suci mereka diyakini oleh umat Islam telah diubah, namun hal tersebut minimal disepakati oleh para ulama sebagai golongan ahl alkitab. (Habieb, 1997, hal. 19)

Umumnya para ulama sepakat membolehkan perkawinan laki-laki muslim dengan wanita ahl al-kitab. Bagi yang memperbolehkan perkawinan semacam ini argumentasi mereka mengacu pada Alquran surat al-Maidah ayat 5 tersebut. Dalam penentuan siapa sajakah yang termasuk kedalam golongan ahl al-kitab, para ulama berbeda pendapat, Muhammad Abduh dan Muhammad Rasyid Rida. Keduanya berpendapat bahwa ahl al-kitab tidaklah sebatas pada orangorang Yahudi dan Nasrani saja. Kedua ulama besar asal Mesir itu menyebutkan bahwa orang-orang Majusi, Sabi'in, penyembah berhala di India, China dan Jepang, seperti penganut agama Hindu, Budha, Kong $\mathrm{Hu}$ Chu dan Shinto, yang percaya pada Tuhan, percaya adanya hidup sesudah kematian adalah termasuk ahl al-kitab yang diduga dahulu mempunyai kitab suci yang dibawa seorang nabi, nabi disini diartikan sebagai pembawa pesan moral,
Taurat dan Injil. Dikatakan demikian, karena pengungkapan ini kadang menunjuk kepada keduannya. Term ahlulkitab yang menunjuk kepada kedua komunitas agama ini, Yahudi dan Nasrani, kadang bernada kecaman dan kadang bernada pujian. Salah satu kecaman terhadap ahl al-kitab adalah disebabkan prilaku mereka yang mencampuradukkan

kebenaran

itu dikaitkan dengan ajaran Alquran bahwa "Allah mengutus kepada setiap umat seorang rasul. (Sihab, 2003, hal. 367-368)

Pendapat Muhammad Abduh dan Rasyid Ridha ini berbeda dengan pendapat Imam Syafi"i, menurutnya istilah ahl al-kitab hanya menunjuk pada orang-orang Yahudi dan Nasrani dari keturunan bani Israil. Alasannya, nabi Musa as dan nabi Isa as, hanya diutus pada bani Israil bukan pada bangsa-bangsa lain. Berdasarkan pendapat ini dapat disimpulkan orang-orang beragama Yahudi dan Nasrani yang berada di negara-negara lain termasuk kalangan Kristen yang berada di Indonesia tidak termasuk kedalam golongan ahl alkitab. (Yaqub, 2005, hal. 22-23) Walaupun samasama membatasi makna ahl al-kitab sebatas pada Yahudi dan Nasrani saja, pendapat Yusuf Qardawi berbeda dengan pendapat Imam Syafi'i yang memaknakan ahl al-kitab hanya kepada orang-orang Yahudi dan Nasrani dari keturunan Israel. Menurut Yusuf Qardawi, Yahudi dan Nasrani dimanapun mereka berada termasuk kedalam golongan ahl alkitab. Pendapat Imam Syafi'i ini lebih mengacu pada tataran etnis, sedangkan pemaknaan ahl al-kitab menurut Yusuf Qardawi lebih pada tataran teologis. (Habieb, 1997, hal. 19)

Sementara Abu Hanifah dan moyoritas pakar hukum lainnya menyatakan bahwa siapa saja yang mempercayai salah seorang nabi, dan kitab yang diturunkan oleh Allah (kitab samawi) maka ia termasuk ahl al-kitab. Sehingga ahl al-kitab tidak 
hanya terbatas pada kelompok penganut agama Yahudi dan Nasrani, bila ada yang percaya kepada Shuhuf nabi Ibrahim as, atau kitab Zabur saja, maka ia pun tergolong ahl al-kitab.

Allah sebelum menurunkan Alquran sebelumnya telah terlebihdahulu menurunkan dua kitab kepada golongan Yahudi dan Nasrani yang kemudian disebut ahlulkitab, jadi jelaslah bahwa yang dimaksud ahlulkitab dalam Alqur'an adalah merujuk kepada kedua kelompok agama ini, karena bagaimanapun juga penafsiran yang terbaik adalah pengkhususan surat al-Maidah ayat 5. Ibnu Rusyd menulis bahwa para ulama sepakat akan kehalalan menikahi perempuan kitabiyah dengan syarat ia merdeka bukan budak. Ibnu Munzir berkata tidak ada dari sahabat yang mengharamkan laki-laki muslim menikahi perempuan kitabiyah. Qurthubi dan Nu"as mengatakan "di antara sahabat yang menghalalkan pernikahan semacam ini antara lain : Utsman, Talhah, Ibnu Abbas, Jabir, dan Hudzaifah. Sedangkan dari golongan tabiin yang menghalalkan adalah Sa"id bin Musayyab, Sa"id bin Jabir, al-Hasan, Mujahid, Thawus, Ikrimah, Syabi, Zhahak dan lainlain. Sayyid Sabiq mencatat hanya ada satu sahabat yang mengharamkan, yakni Ibnu Umar, namun pendapat Ibnu Umar tersebut dikritik habis-habsan oleh an-Nahhas salah seorang ahli tafsir di antara sahabat yang mempunyai pengalaman menikahi wanita kitabiyah adalah Utsman r.a menikah dengan Nailah binti Qaraqisah Kalbiyah yang beragama Nasrani, Hudzaifah menikahi perempuan Yahudi dari penduduk Madian, Jabir dan Sa"ad bin Abu Waqas pernikah menikah dengan perempuan Yahudi dan Nasrani. (Sabiq, 1977, hal. I0I)

Setelah melakukan kajian yang relatif meluas dan mendalam dengan tetap membenarkan prinsip kemaslahatan menyangkut perundang-undangn dan juga pendapat ulama yang ada yang kebanyakan mengharamkan dan bahkan tidak mengesahkan hukum pernikahan beda agama penulis bisa penafsiran ayat dengan ayat, sebagaimna yang diungkapkan oleh Ibnu Katsir dalam Tafsir al-Quran al Azhim berkata. "maka jika ada orang yang bertanya bagaimanakah cara tafsir yang paling baik? Maka jawabannya adalah menafsirkan ayat dengan ayat, sebab adakalnya yang tersebut secara global pada suatu ayat, disebutkan rinciannya pada ayat yang lain.

Dalam hukum Islam diperbolehkan (halal) menikahi wanita ahl al-kitab berdasarkan memahami walaupun belum tentu membenaarkan dan mendukung pendapat tersebut, hemat penulis pernikahan beda agama itu bersifat kasuistis yang harus dipilih-pilih ketentuan hukumnya, dalam arti tidak bisa dipukul rata misalnya semua pernikahan beda agama itu halal dan sah, atau semua pernikahan beda agama ini haram dan tidak sah.

Karna penulis beranggapan bahwa kasus pernikahan beda agama ini bersifat kondisional, adakalnya boleh dan ada kalanya tidak boleh, anggapan penulis ini berangkat dari kedua sumber hukum yang yang dipakai yaitu Qs. al-Baqarah, dan al-Ma"idah ayat 5, karna menurut penulis ayat tersebut tidak ada yang saling menghapus (nasakh man sukh), namun penulis melihat ayat tersebut tetap bisa dijadikan landasan hukum pernikahan beda agama, sesuai dengan konteks yang dihadapi, semisal apabila ada konflik maka pernikahan semacam ini tidak diperbolehkan, namun apabila umat beragam hidup rukun berdampingan maka bisa diberlakukan ayat 5 suarat al-maidah dengan memberikan legitimasi terhadap pernikahan beda agama. Apalagi ketika pernikahan itu disejajarkan dengan muamalah pada umumnya dan disejajarkan dengan makanan dan minuman (Qs.al-mumtahanah ayat 10) yang halal maka kasus pernikahan beda agama itu dibolehkan atau bahkan dihalalkan selama dalam konteks tertentu. 
Atas beberapa alasan diatas, maka untuk menetapkan kasus hukum pernikhan beada agama yang situasional dan bisa berbeda-beda hukumnya ini juga didasarkan (bergantung) kepada motivasi, niat, maksud, tujuan dan keimanan seorang muslim yang akan melakukan pernikahan beda agama, penulis menyaratkan keimanan sebagai hal yang prinsip apabila akan menumpuh pernikahan beda agama karna dalam surat yang dikalaim pembolehan nikah beda agama diawali dengan (kalimat hai orang-yang beriman) karna memang apabila melihat sejarah pernikahan semacam ini merupakan motif kepada hukum agama ( UU No. I 1994, Pasal 2 ayat I), sedang didalam agama hukum perkawinan beda agama terdapat beragam pendapat, ini menggambarkan tidak adanya kepastian hukum dan ketidak samaan dihadapan hukum. Melihat hal tersebut dapat dikatakan bahwa perkawinan antar agama sama sekali tidak diatur dalam UU No. I//974, oleh karena itu berdasarkan Pasal 66 UU No. I/I974 maka persoalan perkawinan beda agama dapat merujuk pada peraturan perkawinan campuran. Bahkan, Undang-Undang No. I Tahun 1974 secara tidak langsung memberikan ruang bagi terjadinya perkawinan beda agama, yaitu dengan memanfaatkan Pasal 56 Undang-Undang No. I Tahun 1974. Artinya pengharaman pernikahan beda agama untuk saat ini sudah tidak relevan lagi, di tambah lagi tidak adanya dalil al-Quran yang secara tegas menyatakan keharamannya, adalah merupakan dalil diperbolehkannya pernikahan beda agama. Kebolehan disini bukan tanpa sarat penulis menyaratkan keimanan sebagai hal pokok apabila akan menumpuh pernikahan beda agama karna dalam surat al-Maidah yang didalamnya terdapat ayat yang membolehkan pernikahan beda agama diawali dengan (kalimat hai orang-yang beriman) karna memang apabila melihat sejarah pernikahan semacam ini merupakan motif berdakwah, hal ini terbukti dengan banyaknya sahabat yang berhasil berdakwah, hal ini terbukti dengan banyaknya sahabat yang berhasil meng Islamkan pesangannya yang berlainan keyakinan.

\section{Kesimpulan}

Sebagai Penutup penulis memberikan beberapa kesimpulan yang dapat ditarik dari pembahasan tersebut yaitu, Status perkawinan beda agama dalam sistem hukum di Indonesia belum di atur secara gamblang dan tegas, kenapa demikian karna didalam Undang-undang No I Tahun 1974 ini sah atau tidaknya sebuah perkawinan dikembalikan meng Islamkan pesangannya. Sedangkan untuk pernikahan beda agama yang laki-lakinya non muslim haram hukumnya karena bertentangan dengan Qs. al-Baqarah 22I, dalam ayat ini Allah Swt, mengharamkan laki-laki non muslim menikahai prempuan muslimah, Jika dibolehkan sebaliknya, tentu al-Qur"an dan al-Sunnah akan menjelaskannya.

\section{Daftar Pustaka}

Abdalla Ulil Absar, Menyegarkan Kembali Pemikiran Islam (Kompas : Senin, 18 November 2002)

Aibak Kutbuddin, Kajian Fiqh Kontemporer, (Yogyakarta; Teras, 2009),

Ariyadi, A. (2019). Tindak Pidana Pelaku Eksploitasi Seksual pada Anak Menurut Hukum Islam. Jurnal Hadratul Madaniyah, 6(I), 43-67.

al-Zuhaili Wabah, al-figh al-Islam wa-Adillatu, Penerjemah; al-Kattani, Abdul Hayyie (Jakarta; Gema Insani, 20I I)

Barkatullah Abdul Halim dan Teguh Prasetyo, Hukum Islam, Menjawab Tantangan Zaman yang Tersus Berkembang, (Yogyakarta : Pustaka Pelajar, 2006),

Departemen Agama Republik Indonesia, Ensiklopedi Islam, cet.Pertama, Jakarta: Direktorat Jenderal Pembinaan Kelembagaan Agama Islam Proyek Peningkatan Prasarana dan Sarana Perguruan Tinggi Agama/IAIN Jakarta, 1987/1988), 
Djaman Nur, Figh Munakahat, cet. I (Semarang: CV. Toha Putra, 1993),

Habieb Sa'di Abu, Ensiklopedi ljmak: Persepakatan Ulama dalam Hukum Islam. Penerjemah Sahal Mahchfudz, dkk (Jakarta: Pustaka Firdaus, 1997)

Halim Abdul, Carina Rizky Ardhani, Keabsahan Perkawinan Beda Agama Diluar Negeri dalam Tinjauan Yuridis, Jurnal Moral Kemasyarakatan Vol. I, No. I, Tahun 2016,

Himpunan Peraturan PerUndang-undangan Republik Indonesia, ( Jakarta : PT. Ichtiar Baru Van Hauve, 1989 ),

Junaedi Dedi, Bimbingan Perkawinan Membina Keluarga Sakinah Menurut Al-Qur"an dan Sunnah, cet. I Jakarta: Akademi Pressindo, 2000),

M. Ghalib M, Ahl al-Kitab Makna Dan Cakupannya, Cet. Pertama, Jakarta: Paramadina, 1998),

M. Karsayuda, Perkawinan Beda Agama (Menakar Nilai-Nilai Keadilan Kompilasi Hukum

Rusli dan R. Tama, Perkawinan Antar Agama dan Masalahnya, (Bandung; Shantika Dharma, 1984),

Sanawiah. (2017). Hukum Keikutsertaan Warga Dayak Ngaju Muslim Dalam Pelaksanaan Upacara Tiwah (Perspektif Ulama Kota Palangka raya. Jurnal Hadratul Madaniyah, 19. Retrieved from http://journal.umpalangkaraya.ac.id/ind ex.php/jhm/article/view/489/448

Sabiq Sayyid, Fiqh al-Sunnah, (Beirut: Dar al-Kitab al-,,Arabi, 1977)

Shihab Muhammad Quraish, Wawasan Alquran: Tafsir Maudhu'i atas Pelbagai Persoalan Umat (Bandung: Mizan, 2003),

Suma Muhammad Amin, Kawin Beda Agama di Indonesia, telaah syari"ah dan qonun, (Tanggerang : Lentera Hati, 20I5),

Syaikhu, S., Ariyadi, A., \& Norwili, N. (2020). Fikih Muamalah: Memahami Konsep dan Dialektika Kontemporer.

Yaqub Ali Mustofa, Nikah Beda Agama dalam Perspektif al-Quran dan Hadis, (Jakarta;Pustaka Firdaus 2005)
Islam), (Yogyakarta: Total Media, 2006),

Muhammad Abduh dan Ridha Rasyid pada Tafsir al-Manar, jilid VI, (Beirut: Dar alMa"rifah,)

Qardawi Yusuf, Fatwa-fatwa Mutakhir Dr.Yusuf Qardawi, Penerjemah, al-Hamid alHusaini (Jakarta: Yayasan al-Hamidy, 1996),

Rofiq Ahmad, Hukum Islam di Indonesia,cet. ke-2 (Jakarta: PT Raja Grafindo Persada 1997.

Ariyadi, Ariyadi. "Tindak Pidana Pelaku Eksploitasi Seksual pada Anak Menurut Hukum Islam." Jurnal Hadratul Madaniyah 6.1 (2019): 4367.

Ariyadi, Ariyadi. "Tindak Pidana Pelaku Eksploitasi Seksual Pada Anak Di Tinjau Dari Hukum Positif." Jurnal Hadratul Madaniyah 5.2 (2018): 7388.

Zuhdi Masyfuk, Masail Fiqhiyyah, (Jakarta: Haji Mas Agung, 1991), 